\title{
THE EFFECT OF INTERACTION VIA SOCIAL MEDIA AND PAST ONLINE SHOPPING EXPERIENCE ON REPURCHASE INTENTION THROUGH TRUST IN TOKOPEDIA APPLICATION USERS IN SURABAYA
}

\author{
Vincent Seber \\ Widya Mandala Catholic University Surabaya \\ vincentseber@ukwms.ac.id
}

\author{
A R T I C L E I N F O \\ Article history: \\ Received : 9 August 2018 \\ Revised : 26 August 2018 \\ Accepted : 27 October 2018
}

JEL Classification:

Key words:

Integration via social media, past online shopping experience, trust, repurchase intention

DOI:

https://doi.org/10.33508/rima.v1i2.2595

\begin{abstract}
A B S T R A C T
This study aims to analyze the effect of interaction via social media and past online shopping experience on repurchase intention through trust in Tokopedia application users in Surabaya. Today, online purchasing through e-commerce is in vogue. Before making a purchase, most people will seek information first to increase their trust, and they can do this by interacting with others. Increasingly sophisticated technology makes this interaction easy because there is already social media. The information shared by someone certainly comes from their experience. E-commerce consumer interaction through social media and consumer shopping experience are important points so that consumers can increasingly trust an ecommerce and repurchase it in e-commerce.

The sampling technique used is non probability sampling by means of purposive sampling. The sample used in this was 150 respondents. The requirements of respondents in this study were at least 17 years old who had made purchases at Tokopedia at least once in the last two months in Surabaya. Data was collected using a questionnaire. The data analysis technique used is SEM analysis with the LISREL program.

The results of the study prove that interaction via social media and the past online shopping experience have a significant effect on trust. Trusts have a significant effect on repurchase intention. Interaction via social media and past online shopping experience has a significant effect on repurchase intention through trust.
\end{abstract}

\section{INTRODUCTION}

Tokopedia is one of the online shopping centers in Indonesia that carries the marketplace business model. Tokopedia allows individuals, small shops and brands to open and manage online stores. From launch to the end of 2015, Tokopedia's essential services can be used by everyone for free. With a vision of "Building a Better Indonesia Through the Internet," Tokopedia has a program to support Micro, Small, and Medium Enterprises (MSMEs) and individuals to develop their businesses by marketing products online. However, in the success of Tokopedia, there are still some application users who give negative reviews about Tokopedia on social media (https://www.tokopedia.com/about/).

Following are some negative reviews about Tokopedia from several Tokopedia application users: 
Figure 1.1: Negative Opinion Customer about Tokopedia 1

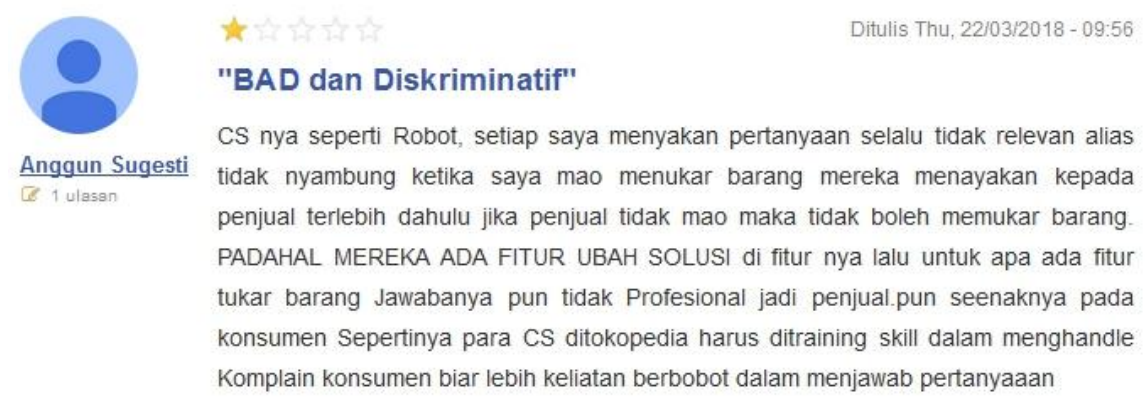

Figure .2: Negative Opinion Customer about Tokopedia 2

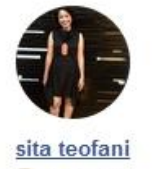

"sistem pembatalan transaksi buruk"

Ditulis Wed, 21/03/2018 - 16:33

saya harus menunggu 2 hari untuk tau apa barang saya benar diproses oleh toko atau tidak. dan saya tidak bisa membatalkan pemesanan saya, uang masuk ke cash tokopedia bukan dikembalikan ke rekeningnya, yang berarti saya harus belanja di tokopedia untuk uang tersebut. dan mungkin dapet toko yang buruk lagi. Terjebak!!!

Other users of social media applications can undoubtedly read these reviews, which will have an impact on reducing the repurchase intention of Tokopedia consumers. In Indonesia alone, social media users are also not insignificant, from research conducted by We Are Social, and Hootsuite noted that there are at least $130,000,000$ people in Indonesia who use social media in 2018 (https://techno.okezone.com/read / 2018/03/13/207/1872093 / this-total-totalusers-social-media-in-Indonesia).

It means that many people will see unfavorable reviews about Tokopedia shared by someone. And this is possible to impact the decline in consumers who will do repurchase intention on Tokopedia. That is because many other e-commerce applications are not inferior to Tokopedia. Figure 1.3, shows that Tokopedia has the second largest number of visitors after Lazada. Still, if many Tokopedia consumers see negative reviews from other Tokopedia consumers, it is most likely to switch to other e-commerce applications, making Tokopedia consumers' repurchase intention level low.

Figure 1.3: Jumlah Pengunjung E-Commerce per Januari 2017

\begin{tabular}{|c|c|c|c|c|}
\hline LAZADA & क्) tokopedia & eleven:a & Utibliblim & Bukalapak \\
\hline 49.000 .000 & 39.666 .667 & 32.666 .667 & 27.000 .000 & 25.666 .667 \\
\hline MATAHARI & Alfacart & blanja & JD.ID & BHINNEKA \\
\hline 18.666.667 & 16.000 .000 & 4.800 .000 & 3.666 .667 & 3.166 .667 \\
\hline
\end{tabular}


Repurchase intention itself is defined as the possibility of consumers interested in buying a product or service (Dodds et al., 1991 in Broekhuizen, 2006). Consumer repurchase intention is very influential on all businesses, including Tokopedia. Having a consumer with a high level of repurchase intention can undoubtedly make a company make a significant profit. And when viewed from Figure 1.3, the number of visitors to Tokopedia is quite a lot but not enough to beat the number of visitors from Lazada. A large number of visitors can be caused by a high level of consumer repurchase intention. However, having a large number of visitors may not necessarily make it even more. This is because many factors can affect the level of repurchase intention of a consumer, such as interaction via social media, past online shopping experience, and trust. And business must be able to think of ways how they can make these factors become positive and have an impact on the level of consumer repurchase intention that increases.

In this day and age, social media is not just a place to connect with one's friends, family, or relatives (Pratomo, 2016). Social media itself is a term that describes various technologies used to bind people into a collaboration, exchange information, and interact through web-based message content (Cross, 2013). Because the internet is always experiencing development, the various technologies and features available to users are ever-changing. This makes social media more hypernym than a specific reference to multiple uses or designs. From this definition, social media can be used to exchange information between people with one another. Therefore, interaction via social media has an essential role in a business. Because the consumer can share their experience in e-commerce. As shown in Figure 1.1 and 1.2, Tokopedia consumers share their negative reviews about their shopping experience at Tokopedia. This certainly can be detrimental to Tokopedia because it can have an impact on reducing the level of repurchase intention from these consumers and other consumers.

Not only interaction via social media can affect the level of repurchase intention of a consumer, but the past online shopping experience of a consumer can also change the level of repurchase intention of consumers. The previous online shopping experience itself is a shopping experience of consumers in online stores that have a direct impact on consumer shopping behavior via the internet (Monsuwe et al., 2004 in Rizwan, 2014). Consumers with firm online repurchase intentions in shopping on the web usually have a past online shopping experience that reduces their uncertainty. From this, it can be seen that e-commerce that has excellent service to each of its customers can increase their consumer's repurchase intention. When viewed from Figure 1.2 and Figure 1.3 shows that Tokopedia consumers have a terrible past online shopping experience. And this certainly can have an impact on reducing the level of repurchase intention from their consumers.

The two previous factors, namely interaction via social media and past online shopping experience, positively influence repurchase intention. However, this influence does not necessarily lead directly to the repurchase plan. But it affects the consumer's trust first before influencing repurchase intention. Trust itself can be defined as a company's willingness to serve the needs that are expected by customers (Mayer et al., 1995 in Broekhuizen, 2006). From the expert's definition, trust is very influential in e-commerce because it can impact consumers' repurchase intentions. If an e-commerce consumer has high confidence in e-commerce, it will positively affect the consumer's repurchase intention.

Conversely, a low level of consumer trust will hurt the consumer's repurchase intention. The level of faith itself is influenced by two previous factors: interaction via social media and past online shopping experience. Someone who has a positive communication via social media and has a right past online shopping experience can increase their trust to make purchases in the e-commerce and vice versa.

These four variables are, of course, 
significant to be examined in Tokopedia. This is because repurchase intention is fundamental in a business or business, both online and offline. After all, a company certainly has a goal to make a profit, and it can be obtained if the consumer of the business has a repurchase intention on its business products. However, getting a high level of repurchase intention requires the influence of other factors, namely interaction via social media, past online shopping experience, and trust. And about Tokopedia, there are still these factors that lead to negative directions, as in Figure 1.2 and 1.3, which will undoubtedly hurt Tokopedia consumers' trust and repurchase intention. Therefore, the model of this research is suited-well to apply in Tokopedia. Because this research model will help Tokopedia in studying the effect of interaction via social media and past online shopping experience of their consumers that affect the level of trust of their consumers so that ultimately repurchase intention from consumers will increase.

From the above background, the researcher took the title for this research, namely "The Effect of Interaction Via Social Media and Past Online Shopping Experience on Repurchase Intention through Trust in Tokopedia Application Users in Surabaya."

\section{LITERATURE REVIEW}

Interaction Via Social Media

At present, many social media platforms have been developed to facilitate the progress of sharing information and creating content in an online context (Chen et al., 2011 in Hajli, 2013). Several social media facilitate these activities, such as Wikipedia, Facebook, YouTube, and Twitter. From some examples of social media, individuals apply social media for different purposes, such as creating online forums and online communities, providing product recommendations or other matters, providing ratings and reviews on an issue, to interacting with other users online.

All of these applications have an effect that can have an impact on ecommerce because most individuals who do online shopping will undoubtedly find a lot of information about purchasing in ecommerce to be able to reduce the perceived insecurity. Reviews are one of the main areas that emerge from interaction via social media. Consumers are actively encouraged by companies to assess and review products and services online (Bronner and de Hoog 2010 in Hajli, 2013). This activity generates information by word of mouth online. Report by word of mouth online is produced through interaction via social media that can help e-commerce increase consumer repurchase intention (Pan and Chiou 2011 in Hajli, 2013).

From the definitions of these experts, researchers can conclude that interaction via social media is to engage between individuals and other individuals to share information carried out through the media. The link can be related to online purchase reviews, recommendations for a product, assess a product distributed by someone who has made online purchases through online forums and online communities that can encourage others to make or not make a purchase in an e-commerce site. For ecommerce business owners, this is very important because it can affect the smooth running of their business. Therefore, ecommerce owners must be able to provide genuinely high-quality services to each of their consumers. If these consumers interact via social media, and they can provide useful information about the products they buy from e-commerce so that they repurchase the intention of others will increase.

\section{Past Online Shopping Experience}

The purpose of shopping online is related to the past online shopping experience via the internet before and has a direct impact on shopping behavior via the internet. Therefore, e-commerce business owners should provide the best service to their customers as they will impact their behavior in the future. Ideas will be related to their repurchase intention in e-commerce (Monsuwe et al. 2004 in Ridwan, 2014).

Customers with firm online 
repurchase intention in shopping on the web usually have a previous purchase experience that helps reduce their uncertainty, from this it can be seen that e-commerce that has excellent service to each customer can increase consumer repurchase intention through e-commerce (Shim and Drake, 1990 in Leeraphong and Mardjo, 2013). Past online shopping experience by someone written on social media can encourage other people's buying intentions. Therefore ecommerce should not only focus on one or two consumers, but they must focus on each customer in terms of serving because we will not know who from each of our consumers will spread the experience of buying a product in e-commerce (Leeraphong and Mardjo, 2013).

From the definitions of the experts, the researcher can conclude that the past online shopping experience is a previous shopping experience in e-commerce that is owned by someone or someone else who shares it through direct conversation or can also be shared with interaction via social media that can affect someone's online repurchase intention. This is a crucial thing for e-commerce because a person's experience in making purchases in their ecommerce can be a profit or loss for their ecommerce, depending on how e-commerce provides services to their consumers.

Excellent service to their customers will create a satisfying experience for their customers, and this will have an impact on these consumers in terms of increasing repurchase intention. Besides, this will also impact the repurchase intention of others if the consumer spreads his experience through social media. And conversely, if the services provided by e-commerce to consumers are improper and even inadequate can provide a disappointing experience to their consumers and have an impact on reducing the consumer's repurchase intention. Besides, if the consumer spreads his frustrating expertise on social media, it will decrease the repurchase intention of others.

\section{Trust}

In a business-to-consumer relationship, trust in electronic vendors, ecommerce, is crucial in assessing risk in transactions. Because forming a consumer, trust is complicated so that extra services must be provided by e-commerce to consumers so that trust can be established (McCole) et al., 2010 in Hajli, 2013). Trust can reduce the uncertainty created by others, and this is very important for e-commerce. Therefore Tokopedia, which is one of ecommerce, must establish trust in consumers that are difficult for others to break so that the business can run smoothly ( P. Blau, 1964 in Leeraphong and Mardjo, 2013).

Trust in the online environment is very important because the complexity and diversity of online interactions can allow for dishonest and unpredictable behavior. It is complicated for consumers to see which ecommerce can be trusted or not, therefore for serious e-commerce should provide the best service without cheat consumers, they will feel the trust given by e-commerce (Gefen et al., 2003 in Hajli, 2013).

From the definitions of these experts, researchers can conclude that trust is crucial for the smooth running of an e-commerce business. In our online world, it is challenging to predict consumer behavior. After all, we do not directly see their body language. Therefore, e-commerce owners must be able to provide the best for their customers, both in terms of service and in terms of products sold. So that trust from their customers can be created, and not only is that what e-commerce needs to do, but they also always have to improve their services that will keep trust from their consumers maintained. If e-commerce consumers' confidence has been high, then their consumers will find it hard to believe in interaction via negative social media spread by other parties to bring down e-commerce. Therefore, consumer trust is something that must be obtained and maintained by ecommerce.

\section{$\underline{\text { Repurchase Intention }}$}

Repurchase intention is a kind of decision making that studies the reasons 
consumers buy a particular brand. This can be learned through interaction via social media between consumers. Still, so that the data can be accurate information, ecommerce must process these data, so that it becomes information that will be useful for business development (Shah et al., 2012 in Mirabi et al., 2015).

Morinez et al. (2007) in Mirabi et al., 2015 define repurchase intention as a situation where consumers tend to buy certain products under certain conditions. It is quite challenging for e-commerce to learn what products are needed by most consumers in the state and a specific time to make consumers buy the products they are looking for in e-commerce. Repurchase intention is an essential key point for consumers when considering and evaluating certain products. Therefore, e-commerce must provide the best product choices to increase repurchase intention from consumers (Keller, 2001 in Jaafar et al., 2013).

From the definitions of these experts, the researcher can conclude that repurchase intention is a consumer's purchase intention for a particular product with specific considerations. Consumers' factors in choosing a product to be purchased are certainly very diverse. This factor is a problem for e-commerce because they will not know for sure what consideration consumers do to make a product purchase. Moreover, consumers will be different from one other consumer. Because of the many uncertain considerations, e-commerce must always serve its customers well and provide many product choices so that the repurchase intention of their customers can increase so that the e-commerce they manage can run well.

\section{Development of Hypotheses}

a. Interaction Via Social Media Influences Trust

Consumer relationships through communication via social media such as communities, reviews, or recommendations tend to build trust in e-commerce. Consumer socialization occurs through social media directly by social interactions between consumers, and indirectly by supporting product involvement (Wang et al., 2012 in Hajli, 2013). Consumer social relations generated through social media interaction significantly influence perceived consumer trust (Pan and Chiou, 2011 in Hajli, 2013). Communication on this platform makes social support. Social support made through interaction via social media can affect trust (Weisberg et al., 2011 in Hajli, 2013). Besides, positive comments, feedback, and high ratings can also lead to a higher level of trust in a vendor (Ba and Pavlou, 2002 in Hajli, 2013). Reviews can be considered useful and can influence consumer trust and repurchase intention through the impression created in consumers' minds about a product or service (Purnawirawan et al. 2012 in Hajli, 2013).

And in previous research conducted by Hajli in 2013, there were also research results which stated that interaction via social media affected trust. The results of the study indicated that communication via social media facilitates relationships between consumers through the internet. And in interaction via social media, consumers share information through online forums, communities, ratings, reviews, and recommendations. Of course, these developments can help e-commerce. And the results of this study found that interaction via social media influences the level of consumer trust.

$\mathrm{H} 1$ : Interaction via social media matters towards trust.

\section{b. Past Online Shopping Experience} Influences Trust

The dimensions of the previous online shopping experience that affect confidence include security, privacy, and reliability (Camp, 2001 in Camp, 2003). Safety is defined as the extent to which consumers trust that the Internet is safe for them to send their personal information to business transactions (Kim and Shim, 2002, in Li and Zhang, 2002). Security plays an essential role in influencing consumer attitudes and repurchase intentions (Salisbury et al., 2001 in Kim, 2004). Because there are currently many perceived risks in 
transmitting personal information, such as assigning credit card numbers to transactions on the Internet (Widows, Trocchia, and Gwinner, 2002 in Wang et al., 2008). Lee and Turban (2001) in $\mathrm{Li}$ and Zhang (2002) suggest that consumers may feel uncomfortable releasing their personal information such as credit cards and social security numbers via the Internet because consumers cannot physically check product quality and monitor transaction security. Kim and Shim (2002) in Delafrooz et al. (2009) emphasize that personal awareness of safety has a significant influence on consumer attitudes and online repurchase intention. If this can be created, the trust will be formed in the minds of consumers.

Chen and Barnes (2007) in Jahangir and Begum (2008) define privacy as consumer trust in the performance of other parties in the environment during a transaction. Lee and Turban (2001) in Li and Zhang (2002) argue that the high level of security and privacy in a past online shopping experience has a positive effect on consumer trust because of the perceived risk of exchanging information. Also, company reliability can influence consumer trust and repurchase intention (Balasubramanian, Konana, and Menon, 2003 in Broekhuizen, 2006). In the web shopping environment, most consumers assume that large companies have better capabilities to increase their trust (Koufaris and HamptonSosa, 2004 in Broekhuizen, 2006). Also, companies with a positive reputation can boost consumer trust (Doney and Cannon, 1997; Figueiredo, 2000 in Broekhuizen, 2006).

Previous research conducted by Leeraphong and Mardjo in 2013 stated that a consumer's past online shopping experience could reduce the perceived risk of increasing consumer trust in e-commerce. The previous online shopping experience of other consumers shared through social media can also increase the confidence of consumers of e-commerce because there is specific information about purchases in e-commerce.

$\mathrm{H} 2$ : Past online shopping experience influences trust. c. Trust Influences Repurchase Intention

Trust and security perceived online play an important role in attitudes towards shopping (Jiyoung, 2009 in Hajli, 2013). Research shows online community members can be mutually assured by exchanging information and their experiences, thereby increasing trust. Consequently, their repurchase intention can increase (Han and Windsor, 2011 in Hajli, 2013). Trust in transactions and networks can influence online buyers (McCole et al., 2010 in Hajli, 2013), and increase their repurchase intention (Lu et al., 2010; Shin 2010 in Hajli, 2013). Interaction via social media and the emergence of Web 2.0 can help customers reduce their risks and increase trust in social life. Applications on Web 2.0 and communication via social media, such as customer ratings and reviews, and participation in online communities, will be an excellent solution to overcome this obstacle. Interactions between users connected in online communities can increase trust (Swamynathan et al., 2008 in Hajli, 2013). Trust is a vital determinant in considering consumer repurchase intention (Gefen 2002; Roca et al., 2009 in Hajli, 2013). The more trust consumers feel, the higher the level of consumer repurchase intention (Han and Windsor 2011 in Hajli, 2013). Therefore, trust tends to influence consumers' repurchase intentions (Pavlou, 2003 in Hajli, 2013).

A study conducted by Hajli in 2013 stated that when consumers have trust in ecommerce, they will have a high repurchase intention in e-commerce. And not only in research by Hajli, but a study by Leeraphong and Mardjo in 2013 also stated the same thing, that trust in e-commerce could influence the level of repurchase intention from consumers.

H3: Trust affects repurchase intention.

d. Interaction Via Social Media and Past Online Shopping Experience Influence Repurchase Intention Through Trust

According to Mayfield (2008) in Mayfield (2008), interaction via social media is understood as a new form of online media. 
The following are some characteristics that are usually possessed by interaction via social media, including:

- Participation (participation), i.e., social media, provides contributions and feedback for interested people.

- Openness, most social media are open to receive feedback and encouragement.

- Conversation: Social media uses a better way of communicating, using a two-way communication conversation method.

- Community (social), social media allows communities to form quickly and can communicate effectively. Because the city is a place where people share the same interests.

- Connectedness (connecting), most types of social media develop because of their connectedness.

From the characteristics above, each user of social media is guided to participate in a community and network in broad scope, not only on a national scale but on a global scale. This advantage of interaction via social media can be one component that can increase consumer repurchase intention. Through interaction via social media, the level of consumer trust can be formed by other social media users. The confidence can grow or decrease depending on the comments, reviews, and ratings of a product that consumers see as harmful. (https://ekonomi.kompas.com/read/2018/ 07/24/212200326/media-social- stillbecome- change- behavior- shopping)

Consumers' past online shopping experience can also increase their repurchase intention towards a product or company. If their previous experience is satisfied, this will increase their trust in e-commerce and increase their repurchase intention again. And vice versa, if the previous experience is felt disappointing, then consumer trust will decrease and allow consumers not to have a repurchase intention in the e-commerce. (http://www.koran-jakarta.com/transaksicomfortable-- shopping--online--tumbuhspat/)

Previous research conducted by Hajli in 2013 also stated that interaction via social media could influence consumer trust through reviews, comments, other people's judgments about e-commerce shared on social media, and it also has an impact on repurchase intention. Research conducted by Leeraphong and Mardjo in 2013 also showed that one's past online shopping experience affected trust and impacted repurchase intention. Not only past online shopping experience yourself, but the property of other consumers who are shared through social media can also affect another consumer trust so that it also affects the level of repurchase intention of other consumers.

$\mathrm{H} 4$ : Interaction via social media is influential against repurchase intention through trust.

H5: Past online shopping experience effect on repurchase intention through trust.

\section{METHODOLOGY}

Research Design

The research design that researchers used in this study were causal research. Understanding the causal relationship itself is a dependent relationship between two or more variables to clarify that one or more variables are related (Hair et al., 1995, in Yamin and Kurniawan, 2009). According to Suryabrata (1983), causal research aims to investigate the possibility of a causal relationship, but not by way of experimentation but carried out by observing data from factors that are suspected to be caused, as a comparison.

This study also includes quantitative research that is systematic scientific research on parts and phenomena and their relationships (Sugiyono, 2013). This quantitative research aims to develop theories and hypotheses relating to interaction via social media, past online shopping experience, trust, and repurchase intention. And this study is a modification of the results of two previous studies, namely, Hajli (2013) and research conducted by Leeraphong and Mardjo (2013).

\section{Definition of Variable Operations}

Interaction Via Social Media

Communication via social media is an individual opinion about Tokopedia's opportunity to connect with other 
consumers through online communities, forums, ratings, reviews, and recommendations to help a person find information about purchases in e-commerce. Referring to research conducted by Vinerean et al. (2013), interaction via social media is measured by the following indicators:

- Tokopedia provides an opportunity for me and other consumers to interact with each other through reviews.

- Tokopedia offers a chance for me and other consumers to communicate with one another through judgment.

- Tokopedia provides an opportunity for me and other consumers to interact with each other through suggestions.

- Tokopedia delivers a chance for different consumers and me to communicate with each other through pictures or photos of the product purchased.

\section{Past Online Shopping Experience}

The past online shopping experience is an experience of individuals making online product purchases in the past at Tokopedia. According to Mosteller, Donthub, and Eroglu (2014) in Trevinal, Coupey, and Stenger (2015), past online shopping experience is measured by the following indicators:

- I feel the product categories in Tokopedia are arranged excitingly.

- I found the product I was looking for easily on Tokopedia.

- I don't spend a lot of time shopping at Tokopedia.

- I don't use much effort when shopping at Tokopedia.

- I feel that transactions on Tokopedia are smooth.

- My experience when shopping at Tokopedia was very pleasant.

\section{$\underline{\text { Trust }}$}

Trust is an individual's belief that Tokopedia can be trusted when he deals with them. The following are indicators used in measuring trust variables (Kim et al., 2008; Heijden et al., 2003; Javernpaa et al., 2000; Pavlou, 2003; Gefen, 2000 in Dachyar and Banjamahor, 2017):
-, I feel that Tokopedia is trusted ecommerce.

- I feel that Tokopedia is e-commerce that guarantees and is responsible to its consumers.

- The services provided by Tokopedia meet my expectations.

- I am convinced that Tokopedia is the best choice in my mind when I want to go shopping online.

\section{Repurchase Intention}

Repurchase intention is an individual's decision to repurchase and recommend Tokopedia to other individuals. This repurchase intention variable is measured by several indicators as follows (Kim et al., 2008; Gefen, 2000; Heijden et al., 2003; Javernpaa et al., 2000; Gefen et al., 2003; Dehua, Lu, and Zhou, 2008; Pavlou, 2003; Venkatesh, 2000 in Dachyar and Banjamahor, 2017):

- I might immediately purchase a product back at Tokopedia.

- I might recommend Tokopedia to my friends.

- It is possible that I will trade with Tokopedia in the future.

\section{Measurement of Variables}

The variable measurement technique in this study uses a five-point Likert scale. Likert scale is a psychometric scale commonly used in questionnaires and is the most widely used in research in the form of surveys. The Likert range itself is used to measure a person's response to a particular thing with which the answers of each instrument have gradations from very positive to very negative. The grading of solutions is as follows (Sugiyono, 2013):

- Alternative anwer strongly agree (SS): score 5.

- Alternative answer agree (S): rating 4.

- Alternative neutral answers $(\mathrm{N})$ : score 3.

- Alternative answers disagree (TS): score 2.

- Alternative answers strongly disagree (STS): score 1.

\section{Types and Sources of Data}

The type of data used in this study is 
the type of quantitative data. Quantitative data is data in the form of numbers (Bungin, 2005). In this study, quantitative data were obtained from the respondents' answers to questionnaires that had been filled out.

While the data source used in this study is the primary data source. Primary data itself is a data obtained directly from the source (Sekaran, 2006 in Mahendra, 2015). In this study, primary data were obtained directly from research respondents who answered the questionnaire given by researchers, namely consumers who have made purchases at Tokopedia.

\section{Data Collection Tools and Methods}

Data collection tools used in this study were questionnaires. The questionnaire is an information collection technique that allows analysts to learn attitudes, beliefs, behavior, and characteristics of people who have the characteristics of respondents following research that can be influenced by the proposed system or existing system.

Data collection methods used in this study are surveys and direct interviews with relevant parties to this research. Survey is a method of collecting primary data by giving questions to individual respondents. The interview is a conversation between two or more people between the source and the interviewer that aims to get reliable information from the source.

\section{Population, Samples, and Sampling Techniques}

According to Sugiyono (2013), the population is a generalization area consisting of objects or subjects with specific quantities and characteristics determined by researchers to be studied and then drawn conclusions. The population in this study is the people of Surabaya who have done online shopping at Tokopedia.

The sample is a portion of the number and characteristics possessed by a population or a small part of a population member taken according to specific procedures so that it can represent the population. The sample in this study is the majority of people of Surabaya who have done online shopping at Tokopedia. According to Hair et al., 1995 in Ghozali and Fuad, 2005, the minimum sample is five times the number of manifest variables (indicators). The number of signs of this study was 17; if the example used five times the amount of indicators, the calculation was $5 \times 17=85$ respondents. Thus the number of samples used in this study were 150 respondents. Taking a more significant amount of samples helps researchers if there are invalid questionnaires so that researchers can use surveys from other respondents.

The sampling technique in this study uses nonprobability sampling by purposive sampling. Non-probability sampling is a technique that does not provide equal opportunity for every element or member of the population to be selected as a sample. While purposive sampling itself is a technique of determining the sample with specific considerations or unique selection. So, the example in this study were respondents who had the following characteristics:

- Residing in Surabaya.

- At least 17 years old (at that age someone has assumed that they can make a purchase decision that is considered to their liking)

- Having an online shopping experience at Tokopedia (at least once), pleasant shopping experience, and lousy shopping experience in 2 months.

\section{$\underline{\text { Data Analysis }}$}

The data analysis technique used in this study is structural equation modeling (SEM). Structural equation modeling (SEM) is an evolution of multiple equations developed from the principles of econometrics and combined with the regulatory policies of psychology and sociology (Ghozali, 2008). In structural equation modeling (SEM), we will examine measurement models, overall models, structural models, and path analysis.

a. Data Normality Test

Yamin and Kurniawan (2009) said that data normality consists of 2 types of output: univariate normality and multivariate normality: 
- In univariate normality, if the p-value chisquare Skewness and Kurtosis are at least 0.05, each variable follows the normal distribution function. Conversely, if the pvalue chi-square Skewness and Kurtosis are less than 0.05, then it can be said that the variable does not follow the normal distribution function.

- In multivariate normality, the p-value chisquare Skewness and Kurtosis are at least 0.05 , this means that all variables follow the normal distribution function. Conversely, if the p-value chi-square Skewness and Kurtosis are less than 0.05 , then it can be said that all variables do not follow the normal distribution function.

\section{$\underline{\text { Data Validity Test }}$}

Validity aims to prove whether an indicator can measure latent variables used in research. According to Ridgon, and Ferguson (1991) and Doll et al. (1994) in Yamin and Kurniawan (2009), a variable is said to have good validity for a latent construct if:

- The value of $\mathrm{t}$ factor load (factor loading) is higher than the critical value $(>1.96$ or practically $>2$ ).

- The standardized factor loading is greater than or equal to 0.7 .

\section{$\underline{\text { Reliability Test }}$}

Reliability is used in research to obtain evidence that the information or data used is trustworthy and can reveal information following reality on the ground. Measurement of construct reliability or size of extract variance. In this study, contract reliability is used where an indicator can be said to be reliable if the value of $C R$ (Construct Reliability),> 0.7 (Yamin and Kurniawan, 2009):

$$
\mathrm{CR}=\frac{\left(\sum \lambda_{i}\right)^{2}}{\left(\sum \lambda_{i}\right)^{2}+\left(\sum \epsilon_{i}\right)}
$$

Information:

$\lambda=$ standardized loading (standard loading

/ loading)

$\mathrm{CR}=$ Construction Reliability

\section{Structural Model Match Test}

Evaluation of structural models is related to testing the relationship between variables that were previously hypothesized. In practice, the test commonly used is twoway testing using a statistical $t$ value limit of 1.96. For the evaluation of the whole structural equation, the coefficient of determination (R2) used is similar to the regression analysis. The decision ratio explains how much the exogenous variables hypothesized in the comparison can define the endogenous variables (Yamin and Kurniawan, 2009).

\section{Overall Model Match Test}

According to Yamin and Kurniawan (2009), the model compatibility test used to test the hypothesized model is a good model for presenting the research results. The overall model fit test discussed in this study includes:

- GFI (Goodness-of-fit Index) is a measure of the model's ability to explain the diversity of data. A good model can be concluded with a value approaching 1 , which generally uses a minimum limit of 0.9 .

- AGFI (Adjusted Goodness of Fit Index) is a modification of GFI by accommodating the free model's degree with other models being compared. If the value of AGFI $\geq 0.9$, then it is said to be a good fit, whereas if it is $0.8 \leq$ AGFI $\leq 0.9$, it is said to be a marginal fit.

- NFI (Normal Fit Index) is the magnitude of the mismatch between the target and base models. If the NFI value is $\geq 0,9$, it is said to be a good fit, whereas if $0,8 \leq \mathrm{NFI} \leq 0,9$, it is said to be a marginal fit.

- IFI (Incremental Fit Index), the value of the IFI if IFI value $\geq 0.9$, then it is said to be a good fit, whereas if $0.8 \leq \mathrm{IFI} \leq 0.9$, then it is said to be a marginal fit.

- CFI (Comparative Fit Index), the value is between $0-1$. CFI value $\geq 0.9$ is a good model. A value of $0.8 \leq \mathrm{CFI} \leq 0.9$ is a marginal fit.

- RFI (Relative Fit Index), the value ranges between 0 and 1 . The RFI value $\geq 0.9$ is a good fit, while the value $0.8 \leq \mathrm{RFI} \leq 0.9$ is marginal fit.

- RMSEA (Root Mean Square Error of Approximation), is a measure of the average 
difference per degree of freedom expected in a population. RMSEA $<0.08$ is good fit, while RMSEA $<0.05$ is close fit.

\section{Hypothesis testing}

Hypothesis testing is needed to determine the significance of the results of calculations with SEM using the SPSS program. Significance testing criteria with a cut off of 1.96. If lambda has tcount> 1.96, then the value of lambda can be significant (Ghozali and Fuad, 2009).

\section{Overview of Research Objects}

Researchers

distributed questionnaires to respondents who used the Tokopedia application and were in Surabaya. At least they made a one-time purchase in the Tokopedia application in the past two months. Questionnaires were distributed on November 9, 2018, to November 19, 2018. From 197 questionnaires distributed by researchers, 47 inquiries were not answered in full because respondents did not match the requirements of this study. Then the researchers used 150 questionnaires that were answered in full by respondents to be processed in hypothesis testing.

\section{Data Description}

\section{Characteristics of Respondents}

The respondent criteria, some requirements must be met that have been set by the researcher. These requirements include: respondents residing in Surabaya; respondents are at least 17 years old; respondents have shopping experience in Tokopedia in the last two months. The following are the characteristics of the respondents used in this study:

- Frequency Distribution of Respondents by Gender

Table 3.1 shows that the number of male respondents is 79 respondents, with a percentage of $52.7 \%$, and the number of female respondents is 71 , with a rate of $47.3 \%$. So, the number of male and female respondents in this study can be almost balanced.
Table 3.1 Frequency Distribution of Respondents by Gender

\begin{tabular}{|c|c|c|}
\hline $\begin{array}{c}\text { Jenis } \\
\text { Kelamin }\end{array}$ & Jumlah & $\begin{array}{c}\text { Persentase } \\
(\%)\end{array}$ \\
\hline Male & 79 & $52,7 \%$ \\
\hline Female & 71 & $47,3 \%$ \\
\hline Total & 150 & $100 \%$ \\
\hline
\end{tabular}

- Frequency Distribution of Respondents by Age

Based on Table 3.2, the highest number of respondents are respondents between the ages of $17-<25$ years, which is 121 respondents, with a percentage of $80.7 \%$. And the least are respondents with age more than 45 years, namely only one respondent with a rate of $0.7 \%$. So, most respondents in this study were aged between $17-<25$ years.

Table 3.2 Frequency Distribution of Respondents by Age

\begin{tabular}{|c|c|c|}
\hline Usia & Jumlah & Percentage $(\%)$ \\
\hline $17-<25$ tahun & 121 & $80,7 \%$ \\
\hline $25-<35$ tahun & 24 & $16,0 \%$ \\
\hline $35-<45$ tahun & 4 & $2,7 \%$ \\
\hline$\geq 45$ tahun & 1 & $0,7 \%$ \\
\hline Total & 150 & $100 \%$ \\
\hline
\end{tabular}

- Frequency Distribution of Respondents Based on Latest Education

Based on Table 3.3, it is known that the majority of respondents in this study had a senior high school education or equivalent, which is 98 respondents with a percentage of $65.3 \%$. Followed by the latest education S1 as many as 43 respondents with a rate of $28.7 \%$. Table 3.3 Frequency Distribution of Respondents Based on Latest Education

\begin{tabular}{|c|c|c|}
\hline Latest Education & Total & Percentage (\%) \\
\hline SMA & 98 & $65,3 \%$ \\
\hline Diploma & 8 & $5,3 \%$ \\
\hline S1 & 43 & $28,7 \%$ \\
\hline Lain-lain & 1 & $0,7 \%$ \\
\hline Total & 150 & $100 \%$ \\
\hline
\end{tabular}


- Frequency Distribution of Respondents by Occupation

Based on Table 3.4, it is known that the majority of respondents in this study have jobs as students of 100 respondents, with a percentage of $66.7 \%$. Followed by 37 private employees with a rate of $24.7 \%$.

Table 3.4 Frequency Distribution of Respondents by Occupation

\begin{tabular}{|c|c|c|}
\hline Occupation & Total & Percentage (\%) \\
\hline Student & 100 & $66,7 \%$ \\
\hline Private employee & 37 & $24,7 \%$ \\
\hline State employee & 2 & $1,3 \%$ \\
\hline Entrepreneur & 11 & $7,3 \%$ \\
\hline Lain-lain & 0 & $0,0 \%$ \\
\hline Total & 150 & $100 \%$ \\
\hline
\end{tabular}

- Frequency Distribution of Respondents by Number of Product Purchases in Tokopedia in the Last Two Months

Based on Table 3.5, it can be seen that the majority of respondents in this study made two purchases of a product in Tokopedia in the last two months, as many as 55 respondents with a percentage of $36.7 \%$. Followed by a one-time purchase of 43 respondents, with a rate of $28.7 \%$.

Table 3.5 Frequency Distribution of Respondents by Number of Product Purchases in Tokopedia in the Last 2 Months

\begin{tabular}{|c|c|c|}
\hline Total Purchase & Total & Percentage (\%) \\
\hline 1 time & 43 & $28,7 \%$ \\
\hline 2 times & 55 & $36,7 \%$ \\
\hline 3 times & 27 & $18,0 \%$ \\
\hline More than 3 times & 25 & $16,7 \%$ \\
\hline Total & 150 & $100 \%$ \\
\hline
\end{tabular}

Descriptive Statistics of Research Variables

Based on the average respondent's answers, then the research interval can be determined (Durianto, et al., 2001 in Dahmiri, 2014):

Interval $=\underline{\text { Nilai tertinggi }- \text { Nilai terendah }}$ Banyaknya kelas

Interval $=\frac{5-1}{8}$

Interval $=0,8$

Based on the above calculation, we can get the criteria from the variables presented in Table 3.6 below:

Table 3.6 Average Interval Score

\begin{tabular}{|c|c|}
\hline $\begin{array}{c}\text { Interval Rata-Rata } \\
\text { Skor }\end{array}$ & $\begin{array}{c}\text { Kriteria Setiap } \\
\text { Variabel }\end{array}$ \\
\hline $1,0-<1,8$ & Sangat Tidak Setuju \\
\hline $1,8-<2,6$ & Tidak Setuju \\
\hline $2,6-<3,4$ & Netral \\
\hline $3,4-<4,2$ & Setuju \\
\hline $4,2-<5,0$ & Sangat Setuju \\
\hline
\end{tabular}

Furthermore, using the classification in Table 3.6, the evaluation of respondents' responses to each variable can be described as follows:

- Descriptive Statistics of Interaction Variables Via Social Media

The following are descriptive statistics of respondents' answers to each indicator in the interaction variable via social media:

Table 3.7 Descriptive Statistics of Interaction Variables Via Social Media

\begin{tabular}{|c|l|c|}
\hline No & \multicolumn{1}{|c|}{ Indicator } & Mean \\
\hline 1. & $\begin{array}{l}\text { Tokopedia provides an } \\
\text { opportunity for me and other } \\
\text { consumers to interact with } \\
\text { each other through reviews. }\end{array}$ & 3,587 \\
\hline 2. & $\begin{array}{l}\text { Tokopedia offers a chance for } \\
\text { me and other consumers to } \\
\text { communicate with one } \\
\text { another through judgement }\end{array}$ & 3,593 \\
\hline 3. & $\begin{array}{l}\text { Tokopedia provides an } \\
\text { opportunity for me and other } \\
\text { consumers to interact with } \\
\text { each other through } \\
\text { suggestions. }\end{array}$ & 3,713 \\
\hline 4. & $\begin{array}{l}\text { Tokopedia delivers a chance } \\
\text { for different consumers and } \\
\text { me to communicate with } \\
\text { each other through pictures } \\
\text { or photos of the product } \\
\text { purchased. }\end{array}$ & 3,560 \\
\hline \multicolumn{1}{|c|}{ Average } & 3,613 \\
\hline
\end{tabular}

Based on Table 3.7, it is known that the interaction variable via social media is measured using four indicators. The average value of the interaction variable via social media is 3,613. This shows that overall, Tokopedia provides an opportunity for application users in Surabaya to interact 
with each other through social media.

- Descriptive Statistics of Past Online Shopping Experience Variables

The following are descriptive statistics of respondents' answers to each indicator in the past online shopping experience variable:

Table 3.8 Descriptive Statistics of Past Online Shopping Experience Variables

\begin{tabular}{|c|l|c|}
\hline No & \multicolumn{1}{|c|}{ Indicator } & Mean \\
\hline 1. & $\begin{array}{l}\text { I feel the product } \\
\text { categories in Tokopedia } \\
\text { are arranged excitingly }\end{array}$ & 3,673 \\
\hline 2. & $\begin{array}{l}\text { I found the product I was } \\
\text { looking for easily on } \\
\text { Tokopedia }\end{array}$ & 3,647 \\
\hline 3. & $\begin{array}{l}\text { I don't spend a lot of time } \\
\text { shopping at Tokopedia }\end{array}$ & 3,873 \\
\hline 4. & $\begin{array}{l}\text { I don't use much effort } \\
\text { when shopping at } \\
\text { Tokopedia }\end{array}$ & 3,827 \\
\hline 5. & $\begin{array}{l}\text { I feel that transactions on } \\
\text { Tokopedia are smooth }\end{array}$ & 3,747 \\
\hline 6. & $\begin{array}{l}\text { My experience when } \\
\text { shopping at Tokopedia } \\
\text { was very pleasant. }\end{array}$ & 3,740 \\
\hline \multicolumn{3}{|c|}{ Average } \\
\hline
\end{tabular}

Based on Table 3.8, it is known that the new online shopping experience variable is measured using six indicators. The average value of the past online shopping experience variable is 3,751 . This shows that overall, Tokopedia application users in Surabaya have a pleasant shopping experience.

- Descriptive Variable Trust Statistics

The following are descriptive statistics of respondents' answers to each indicator on the trust variable:

Table 3.9 Descriptive Variable Trust Statistics

\begin{tabular}{|c|l|c|}
\hline No & \multicolumn{1}{|c|}{ Indicator } & Mean \\
\hline 1. & $\begin{array}{l}\text { I feel Tokopedia is trustworthy } \\
\text { e-commerce. }\end{array}$ & 3,920 \\
\hline 2. & $\begin{array}{l}\text { I feel Tokopedia give me } \\
\text { guarantee and responsibility } \\
\text { for consumers. }\end{array}$ & 3,833 \\
\hline 3. & $\begin{array}{l}\text { Tokopedia can filling my } \\
\text { expectations. }\end{array}$ & 3,760 \\
\hline
\end{tabular}

\begin{tabular}{|c|l|c|}
\hline 4. & $\begin{array}{l}\text { I believe Tokopedia is one of } \\
\text { the best choice when I wanna } \\
\text { shopping. }\end{array}$ & 3,807 \\
\hline \multicolumn{2}{|c|}{ Average } & 3,830 \\
\hline
\end{tabular}

Based on Table 3.9, it is known that the trust variable is measured using four indicators. The average value of the trust variable is 3,830 . This shows that overall, Tokopedia application users in Surabaya trust the services and products provided by Tokopedia.

- Descriptive Statistics of Repurchase Intention Variables

The following are descriptive statistics of respondents' answers to each indicator on the repurchase intention variable:

Table 3.10 Descriptive Variable Repurchase Intention Statistics

\begin{tabular}{|c|l|c|}
\hline No & \multicolumn{1}{|c|}{ Pernyataan } & Mean \\
\hline 1. & $\begin{array}{l}\text { I might immediately purchase } \\
\text { a product back at Tokopedia }\end{array}$ & 3,907 \\
\hline 2. & $\begin{array}{l}\text { I might recommend } \\
\text { Tokopedia to my friends }\end{array}$ & 3,913 \\
\hline 3. & $\begin{array}{l}\text { It is possible that I will trade } \\
\text { with Tokopedia in the future. }\end{array}$ & 3,800 \\
\hline \multicolumn{2}{|c|}{ Average } & 3,873 \\
\hline
\end{tabular}

Based on Table 3.10, it is known that the repurchase intention variable is measured using three indicators. The average value of the repurchase intention variable is 3,873 . This shows that overall, Tokopedia application users in Surabaya have a high desire to repurchase the products offered by Tokopedia.

\section{Results of Data Analysis}

\section{Normality test}

The normality test in this study uses two criteria, namely univariate normality, and multivariate normality. Univariate normality is used to test each indicator, and multivariate normality is used to test all indicators that make up the research model. Univariate normality test results can be seen in Table 3.11 below:

Table 3.11 Univariate Normality Table \begin{tabular}{|l|l|l|l|} 
No & Variabel & Skewness & Keterangan \\
\hline
\end{tabular} 


\begin{tabular}{|c|c|c|c|}
\hline & & $\begin{array}{c}\text { dan } \\
\text { Kurtosis } \\
\text { P-Value }\end{array}$ & \\
\hline 1. & IVSM1 & 0,254 & Normal \\
\hline 2. & IVSM2 & 0,031 & Not Normal \\
\hline 3. & IVSM3 & 0,010 & Not Normal \\
\hline 4. & POSE1 & 0,023 & Not Normal \\
\hline 5. & POSE2 & 0,008 & Not Normal \\
\hline 6. & POSE3 & 0,075 & Normal \\
\hline 7. & POSE4 & 0,095 & Normal \\
\hline 8. & POSE5 & 0,000 & Not Normal \\
\hline 9. & POSE6 & 0,041 & Not Normal \\
\hline 10. & $\mathrm{~T} 1$ & 0,000 & Not Normal \\
\hline 11. & $\mathrm{~T} 2$ & 0,000 & Not Normal \\
\hline 12. & T3 & 0,000 & Not Normal \\
\hline 13. & $\mathrm{~T} 4$ & 0,013 & Not Normal \\
\hline 14. & RI1 & 0,002 & Not Normal \\
\hline 15. & RI2 & 0,031 & Not Normal \\
\hline 16. & RI3 & 0,111 & Normal \\
\hline
\end{tabular}

Based on Table 3.11, it appears that univariately, the assumption of normality in most indicators is not fulfilled because the $\mathrm{p}$ value is less than the set cutoff of 0.05 . Besides, there is one variable that is dropped by the researcher, namely the IVSM4 variable. That is because in the reliability test, if the IVSM4 variable is declined, it will make the Cronbach's alpha of the IVSM variable more substantial, 0.843. And researchers drop from the beginning of the test, which is the normality test because this will also affect the value of multivariate normality. Multivariate normality test itself by to decide overall the data is declared sane or not, so the change in importance in the multivariate normality test is fundamental.

\section{Table 3.12 Multivariate Normality Table}

\begin{tabular}{|c|c|}
\hline \multicolumn{2}{|c|}{ Skewness dan Kurtosis } \\
\hline Chi-Square & P-Value \\
\hline 3,243 & 0,198 \\
\hline
\end{tabular}

Based on Table 3.12 shows that the data are declared multivariate normal because the $p$-value of skewness and kurtosis is more significant than 0.05 , which is equal to 0.198 , so the analysis can be continued.

\section{Validity test}

Validity test has the aim to prove whether an indicator can measure latent variables used in research. A variable is said to have good validity if the value of $t$ in the loading factor is greater than the cut off of 1.96 (Ridgon and Ferguson, 1991; Doll et al., 1994 in Yamin and Kurniawan, 2009). In this study, researchers conducted a validity test for the $t$ value in factor loading, as seen in Table 3.13.

Table 3.13 Validity Test Results Table

\begin{tabular}{|c|c|c|}
\hline Indikator & $\begin{array}{c}\text { Factor Loading (T- } \\
\text { Value) }\end{array}$ & Keterangan \\
\hline IVSM1 & - & Acuan \\
\hline IVSM2 & 10,91 & Valid \\
\hline IVSM3 & 9,83 & Valid \\
\hline POSE1 & - & Acuan \\
\hline POSE2 & 15,09 & Valid \\
\hline POSE3 & 12,61 & Valid \\
\hline POSE4 & 12,55 & Valid \\
\hline POSE5 & 10,51 & Valid \\
\hline POSE6 & 9,67 & Valid \\
\hline T1 & - & Acuan \\
\hline T2 & 7,39 & Valid \\
\hline T3 & 6,64 & Valid \\
\hline T4 & 5,87 & Valid \\
\hline RI1 & - & Acuan \\
\hline RI2 & 8,87 & Valid \\
\hline RI3 & 7,37 & Valid \\
\hline
\end{tabular}

Based on Table 3.13 shows that the overall indicator is declared valid because the $t$ value of all indicators has a factor loading higher than 1.96 .

\section{$\underline{\text { Reliability Test }}$}

According to Yamin and Kurniawan (2009), the measure of construct reliability can be reliable if it is more than 0.7. The results of the calculation of each variable's construct reliability are shown in Table 3.14 to Table 3.17.

- Construct Reliability Variable Interaction Via Social Media (IVSM)

Table 3.14 IVSM Construct Reliability Test Calculation Results

\begin{tabular}{|c|c|c|c|}
\hline Indikator & $\lambda$ & $\lambda^{2}$ & $\mathrm{e}=\left(1-\lambda^{2}\right)$ \\
\hline IVSM1 & 0,79 & 0,6241 & 0,3759 \\
\hline IVSM2 & 0,91 & 0,8281 & 0,1719 \\
\hline ISVM3 & 0,71 & 0,5041 & 0,4959 \\
\hline$\sum$ & 2,41 & & 1,0437 \\
\hline
\end{tabular}


Calculation of construct reliability variable interaction via social media is as follows:

Construct Reliability $=\quad 2,41^{2}$

$$
\begin{aligned}
& \overline{(2,41)^{2}+1,0437} \\
= & 0,8476750635
\end{aligned}
$$

The calculation of construct reliability interaction variables via social media in Table 3.14 has a reliability value of 0.85 , so it can be concluded that the interaction variable via social media is reliable because it exceeds the cut-off that is $>0.7$.

- Construct Reliability Variable Past Online Shopping Experience (POSE)

Table 3.15 POSE Construct Reliability Test Calculation Results

\begin{tabular}{|c|c|c|c|}
\hline Indicator & $\lambda$ & $\lambda^{2}$ & $\mathrm{e}=\left(1-\lambda^{2}\right)$ \\
\hline POSE1 & 0,77 & 0,5929 & 0,4071 \\
\hline POSE2 & 0,86 & 0,7396 & 0,2604 \\
\hline POSE3 & 0,77 & 0,5929 & 0,4071 \\
\hline POSE4 & 0,74 & 0,5476 & 0,4524 \\
\hline POSE5 & 0,68 & 0,4624 & 0,5376 \\
\hline POSE6 & 0,77 & 0,5929 & 0,4071 \\
\hline$\sum$ & 4,59 & & 2,4717 \\
\hline
\end{tabular}

$$
\begin{aligned}
\text { Construct Reliability } & =\frac{4,592}{(4,59)^{2}+2,4717} \\
& =0,8949991079
\end{aligned}
$$

The calculation of the construct reliability of the past online shopping experience variable in Table 3.15 has a reliability value of 0.89 , so it can be concluded that the previous online shopping experience variable is reliable because it exceeds the cut-off $>0.7$.

- Construct Reliability Variable Trust (T)

Table 3.16 Construct Reliability Test Calculation Results T

\begin{tabular}{|c|c|c|c|}
\hline Indikator & $\lambda$ & $\lambda^{2}$ & $\mathrm{e}=\left(1-\lambda^{2}\right)$ \\
\hline T1 & 0,65 & 0,4225 & 0,5775 \\
\hline T2 & 0,68 & 0,4624 & 0,5376 \\
\hline T3 & 0,68 & 0,4624 & 0,5376 \\
\hline T4 & 0,62 & 0,3844 & 0,6156 \\
\hline$\sum$ & 2,63 & & 2,2683 \\
\hline
\end{tabular}

$$
\begin{aligned}
\text { Construct Reliability } & =\frac{2,63^{2}}{(2,63)^{2}+2,2683} \\
& =0,7530483822
\end{aligned}
$$

From the calculation of the construct reliability of the trust variable in Table 3.16 has a reliability value of 0.75 , so it can be concluded that the trust variable is reliable because it exceeds the cut-off that is $>0.7$.

- Construct Reliability Variable Repurchase Intention (RI)

Table 3.17 The Result of RI Construct Reliability Test Calculation

\begin{tabular}{rl|c|c|c|}
\hline Indikator & $\lambda$ & $\lambda^{2}$ & $\mathrm{e}=\left(1-\lambda^{2}\right)$ \\
\hline RI1 & 0,75 & 0,5625 & 0,4375 \\
\hline RI2 & 0,81 & 0,6561 & 0,3439 \\
\hline RI3 & 0,69 & 0,4761 & 0,5239 \\
\hline$\sum$ & 2,25 & & 1,3053 \\
\hline
\end{tabular}

The calculation of construct reliability variable repurchase intention in Table 3.17 has a reliability value of 0.79 , so it can be concluded that the repurchase intention variable is reliable because it exceeds the cutoff of $>0.7$.

From the calculation of all construct reliability above, it can be concluded that each variable in this study is reliable because it exceeds the set cutoff of $>0.7$.

\section{Structural Model Match Test}

The following is a structural equation from the results of data processing in this study:

$\mathrm{T}=0,24 * \mathrm{IVSM}+0,48 * \mathrm{POSE}$

$\mathrm{RI}=0,95^{*} \mathrm{~T}$

Based on the structural equation model, structural equation models can be constructed as follows:

- Interaction via social media (IVSM) has a positive effect on trust (T) with a coefficient value of 0.24 . This shows that if interaction via social media increases and other independent variables are constant, the trust will also increase.

- Past online shopping experience (POSE) has a positive effect on trust $(\mathrm{T})$ with a coefficient value of 0.48 . This shows that if the past online shopping experience increases and other independent variables are constant, the trust will also increase.

- Trust (T) has a positive effect on repurchase intention (RI) with a coefficient value of 0.95 . This shows that if trust 
increases and other independent variables are constant, repurchase intention will also increase.

\section{Overall Model Match Test}

The model fit test is used to test the hypothesized model is a useful model for presenting the results of research (Yamin and Kurniawan, 2009). The following are the results of the overall model fit test shown in Table 3.18.

Table 3.18 Overall Model Match Test

\begin{tabular}{|c|c|c|c|}
\hline $\begin{array}{c}\text { Goodness } \\
\text { of Fit }\end{array}$ & $\begin{array}{c}\text { Cut of } \\
\text { Value }\end{array}$ & Result & Notes \\
\hline GFI & $\geq 0,9$ & 0,86 & $\begin{array}{c}\text { Marginal } \\
\text { Fit }\end{array}$ \\
\hline AGFI & $\geq 0,9$ & 0,81 & $\begin{array}{c}\text { Marginal } \\
\text { Fit }\end{array}$ \\
\hline NFI & $\geq 0,9$ & 0,93 & Good Fit \\
\hline IFI & $\geq 0,9$ & 0,96 & Good Fit \\
\hline CFI & $\geq 0,9$ & 0,96 & Good Fit \\
\hline RFI & $\geq 0,9$ & 0,91 & Good Fit \\
\hline RMSEA & $<0,08$ & 0,08 & Good Fit \\
\hline
\end{tabular}

Based on the test results of Table 3.18, it can be explained that NFI, IFI, CFI, RFI, RMSEA meet the cut off value so that it can be declared a good fit. GFI and AGFI almost achieve the reduction of benefit so that it can be declared marginal fit. Based on the information above, this research model can be accepted. This is because the number of fit models is more significant, so it can be used to predict each independent variable's effect on the dependent variable.

\section{Hypothesis testing}

Hypothesis testing is needed to determine the significance of the results of calculations with SEM using the SPSS program. This hypothesis testing criteria apply a cut off of 1.96. If each variable relationship has an at-value higher than 1.96, then the link is declared significant (Ghozali and Fuad, 2009). The following are the results of testing the hypotheses shown in
Table 3.19.

Table 3.19 Hypothesis Test Results

\begin{tabular}{|c|c|c|l|}
\hline Hipotesis & $\begin{array}{c}\text { Loading } \\
\text { Factor }\end{array}$ & $\begin{array}{c}\text { T- } \\
\text { Value }\end{array}$ & Notes \\
\hline H1 & 0,24 & 3,97 & Signifikan \\
\hline H2 & 0,48 & 5,49 & Signifikan \\
\hline H3 & 0,95 & 6,36 & Signifikan \\
\hline H4 & 0,23 & 4,11 & Signifikan \\
\hline H5 & 0,46 & 5,86 & Signifikan \\
\hline
\end{tabular}

Based on Table 3.19, the results of hypothesis testing can be explained as follows:

- Interaction via social media (IVSM) has a positive and significant effect on trust $(\mathrm{T})$. The result can be seen with a loading factor value of 0.24 and a $t$-value of 3.97 , which exceeds the specified cut-off (T-Value> 1.96). Thus H1 is accepted.

- Past online shopping experience (POSE) has a positive and significant effect on trust (T). This influence can be seen with a loading factor value of 0.48 and a t-value of 5.49, which exceeds the specified cut-off (TValue $>1.96$ ). Thus $\mathrm{H} 2$ is received.

- Trust (T) has a positive and significant effect on repurchase intention (RI). The influence can be seen with a loading factor of 0.95 and a t-value of 6.36 , which exceeds the specified cut-off (T-Value> 1.96). Thus H3 is accepted.

- Interaction via social media (IVSM) has a positive and significant effect on repurchase intention (RI) through a trust (T). The influence can be seen with a loading factor value of 0.23 and $t$-value of 4.11 , which exceeds the specified cut-off (T-Value> 1.96). Thus H4 is accepted.

- Past online shopping experience (POSE) has a positive and significant effect on repurchase intention (RI) through a trust $(\mathrm{T})$. The influence can be seen with a loading factor value of 0.46 and a t-value of 5.86, which exceeds the specified cut-off (TValue> 1.96). Thus H4 is accepted.

\section{$\underline{\text { Discussion }}$}

Interaction Via Social Media Influences Trust

Based on respondents' assessment of interaction variables via social media on 
Tokopedia application users in Surabaya, it can be seen that the average rating for these variables is included in the agreed category. This means that Tokopedia application users in Surabaya agree that Tokopedia provides opportunities for consumers to interact with each other through social media. Based on the hypothesis testing results, it can be explained that the interaction variable via social media has a positive and significant effect on the trust variable on Tokopedia application users in Surabaya.

According to Chen et al. (2011), in Hajli (2013), currently, a large number of social media platforms have been developed to facilitate the progress of sharing information and creating content in an online context. Whereas trust itself in the online environment is crucial because the complexity and diversity of online interactions can enable behavior that is not sincere and unpredictable (Gefen et al., 2003 in Haijli, 2013). The two expert opinions indicate that the purchase of a product in ecommerce is very high risk because consumers can not see the product you want to buy directly. The transaction is also vulnerable to fraud. Therefore, most online consumers usually want to reduce their uncertainty by finding information in advance. This can be done by consumers by interacting with other consumers through social media to get information that can reduce their possibility. The results of this study are also supported by research conducted by Hajli (2013), which is also a reference journal in this study. The results of the study indicate that there is a positive relationship between social media and trust. The results of the study explained that consumers could interact with each other through social media. The interaction can be in the form of information sharing by consumers through online forums, communities, ratings, reviews, and recommendations. And this will affect consumer trust. Therefore, Tokopedia should really pay attention to this because consumer interaction on social media can affect the level of trust from Tokopedia consumers.
Past Online Shopping Experience Influences $\underline{\text { Trust }}$

Based on the respondents' evaluation of the previous online shopping experience variable on Tokopedia application users in Surabaya, it can be seen that the average rating for that variable is included in the agreed category. This means that Tokopedia application users in Surabaya agree that the user has a good and pleasant experience when purchasing Tokopedia. Based on the results of hypothesis testing, it can be explained that the past online shopping experience variable has a positive and significant effect on the trust variable on Tokopedia application users in Surabaya.

According to Monsuwe et al. (2004), in Ridwan (2014), the purpose of shopping online relates to a person's past online shopping experience and has a direct impact on their subsequent shopping behavior. And according to Mayer et al. (1995) in Broekhuizen (2006), trust itself can be defined as the company's willingness to serve the needs that are expected by customers. The two expert definitions show that the past online shopping experience influences trust because consumers who have had a pleasant shopping experience in e-commerce feel that e-commerce has provided services expected by these consumers to make consumers have trust in e-commerce. The explanation is also following the results of research from Leeraphong and Mardjo (2013), which also became a reference journal in this study. The results of this study indicate that the past online shopping experience has a positive influence on trust. The research explains that a person's shopping experience in ecommerce can affect the level of trust that person has. A good and pleasant shopping experience owned by someone will increase the trust of that person. This is because someone who has a pleasant and enjoyable shopping experience before already has expectations that align with their expectations, making them more trustworthy in e-commerce. Therefore, Tokopedia needs to pay attention to this by 
providing the best possible products and services to increase consumer trust.

\section{Trust Influences Repurchase Intention}

Based on the respondents'

assessment of the trust variable on Tokopedia application users in Surabaya, it can be seen that the average rating for that variable is included in the agreed category. This means that Tokopedia application users in Surabaya agree that they trust the services and products offered by Tokopedia. Based on the results of hypothesis testing, it can be explained that the trust variable has a positive and significant effect on the repurchase intention variable on Tokopedia application users in Surabaya.

According to McCole et al. (2010), in Hajli (2013), in a business-to-consumer relationship, trust in electronic vendors, namely e-commerce, is crucial in assessing risk in transactions. And according to Keller (2001) in Jaafar et al. (2013), repurchase intention is an essential key point for consumers to consider and evaluate certain products. The two definitions show that repurchase intention is influenced by the trust because consumers who have a high level of repurchase intention mean that they have high trust in e-commerce, making consumers feel safe when they make repeat purchases in the e-commerce. The results of this study are consistent with the results of research from two reference journals in this study. Research conducted by Hajli (2013) and research conducted by Leeraphong and Mardjo (2013) both have research results that state that trust influences repurchase intention. The study explains that when consumers have a high level of trust in ecommerce will make these consumers have a high level of repurchase intention. And vice versa, when e-commerce cannot make consumers have high enough trust, it will make the repurchase intention level of the consumer low.

Interaction Via Social Media Influences Repurchase Intention Through Trust

Based on the results of hypothesis testing, it can be explained that the interaction variable via social media is stated to have a positive and significant effect on the repurchase intention variable through the trust variable on Tokopedia application users in Surabaya. In other words, interactions between consumers of Tokedia on social media such as information sharing, reviews, and positive ratings can increase the trust of these consumers, which also has an impact on improving repurchase intention towards the products offered by Tokopedia.

According to Pan and Chiou (2011), in Hajli (2013), information through word of mouth online is produced through interaction via social media that can help ecommerce increase consumer trust. Meanwhile, according to Shah et al. (2012), in Mirabi et al. (2015), repurchase intention is a kind of decision making that studies the reasons consumers buy a particular brand. From the definition of these experts shows that repurchase intention can be influenced by interaction via social media because communication via social media itself helps e-commerce in increasing the trust of their consumers with which a consumer who already has a high level of trust in ecommerce can increase repurchase their intention towards e-commerce. The results of this study are also supported by research conducted by Hajli (2013), who became the reference journal in this study. The study results stated that trusts that are influenced by interaction via social media through reviews, comments, information sharing, and ratings also significantly affect repurchase intention. Consumers who interact through social media get positive information that will make the level of trust from these consumers increase and also have an impact on improving repurchase intention. And vice versa, when consumers who interact through social media get negative information will make the level of trust from consumers decreases and also has an impact on decreasing their repurchase intention.

Past Online Shopping Experience Influences Repurchase Intention Through Trust 
Based on the hypothesis testing results, it can be explained that the past online shopping experience variable is stated to have a positive and significant effect on the repurchase intention variable through the trust variable on Tokopedia application users in Surabaya. This means e-commerce consumers who have enjoyable shopping experience in the past will have high trust. It will also have an impact on increasing repurchase intention from these consumers.

According to Shim and Drake (1990) in Leeraphong and Mardjo (2013), customers with strong online repurchase intentions for shopping on the web usually have past online shopping experiences that reduce their uncertainty. Meanwhile, according to P. Blau (1964) in Leeraphong and Mardjo (2013), trust can reduce the possibility created by other people, and it is crucial for e-commerce. And according to Morinez et al. (2007), in Mirabi et al. (2015), define repurchase intention as a situation where consumers tend to buy certain products under certain conditions. From the definition of these experts, the past online shopping experience of a consumer in e-commerce can help influence consumer trust and also affect the level of repurchase intention. This study's results are also by the results of research from the reference journals, namely research conducted by Leeraphong and Mardjo (2013). The research explains that the past online shopping experience has a positive effect on trust, which then also influences repurchase intention. This shows that a pleasant experience when shopping at e-commerce can make that person become more trusting in e-commerce and make the level of repurchase intention increases. Conversely, when someone has an unpleasant shopping experience on ecommerce will make that person distrust ecommerce and establish the level of repurchase intention below.

\section{CONCLUSION}

Based on the results of the discussion, the conclusions in this study are as follows:

- Interaction via social media (IVSM) has a positive and significant influence on trust (T). It can be concluded that the more positive interaction via social media by Tokopedia consumers will make these consumers have high trust in Tokopedia. Thus it has been proven that hypothesis 1 , which states that communication via social media influences trust, is accepted.

- Past online shopping experience (POSE) has a positive and significant influence on trust (T). It can be concluded that the better past online shopping experience owned by a Tokopedia consumer will increase the trust of these consumers towards Tokopedia. Thus, hypothesis 2, which states the prior online shopping experience, has an effect on the trust received.

- Trust $(\mathrm{T})$ has a positive and significant influence on repurchase intention (RI). It can be concluded that the higher level of Tokopedia consumer trust will make the repurchase intention level of the consumer higher. Thus it has been proven that hypothesis 3, which states that trust influences repurchase intention, is accepted.

- Interaction via social media (IVSM) has a positive and significant influence on repurchase intention (RI) through a trust (T). It can be concluded that the more positive interaction via social media conducted by Tokopedia consumers will make the level of consumer trust higher and higher, which will have an impact also on increasing consumer repurchase intention. Thus it has been proven that hypothesis 4 , which states that interaction via social media influences repurchases intention through trust, is accepted.

- Past online shopping experience (POSE) has a positive and significant influence on repurchase intention (RI) through a trust $(\mathrm{T})$. It can be concluded that the better past online shopping experience owned by Tokopedia consumers will make the level of consumer trust become high and have an impact as well on increasing consumer repurchase intention. Thus it has been proven that hypothesis 5, which states the past online shopping experience affects repurchase intention through trust, is accepted. 


\section{REFERENCE}

Al-Nasser, et al. 2016. Mediating Effect of eService Quality Perceptions on Attitude and Trust Toward Online Shopping. Medwell Journals. 10 (3): 228-240.

Ambar. 2017. 20 Pengertian Media Sosial Menurut Para Ahli. https://pakar komunikasi.com/pengertian-media-sosialmenurut-para-ahli. Diakses Tanggal 08 September 2018.

Anonim. 2016. How the Shopping Experience Has Changed Over the Past Decade. https://www.futurepay.com/ blog /shoppingexperience-changed-past-decad -e/. Diakses Tanggal 11 April 2018.

Anonim. 2018. About Tokopedia. https:// www.tokopedia.com/about/. Diakses Tanggal 07 September 2018.

Anonim. 2018. Reviews Tokopedia. https://trustedcompany.com/id/reviewstokopedia.com. Diakses Tanggal 19 Mei 2018.

Anonim. 2018. Transaksi Nyaman, Belanja "Online" Tumbuh Pesat. http://www.koranjakarta.com/transaksi-nyaman--belanja-online--tumbuh-pesat/. Diakses Tanggal 09 September 2018.

Broekhuizen, J. 2006. Understanding Channel Purchase Intentions: Measuring Online and Offline Value Perceptions. Disertasi. Universitas Groningen.

Bungin, B. 2005. Metodologi Penelitian Kualitatif. Edisi 2. Prenada Media Group. Jakarta.

Camp, L.J. 2003. "Design fot Trust," Trust, Reputation and Security: Theories and Practice. Tesis. Universitas Berlin.

Dachyar, M., dan Banjarnahor. 2017. Factors Influencing Purchase Intention Towards Consumer-to-Consumer e-Commerce. IC Journal. 13 (5): 946-968.

Dahmiri. 2014. Analisis Karakteristik Pribadi dan Evaluasi Konsumen Terhadap Produk Handphone Merek Blackberry. Menkeu. 3
(1): 417-428.

Dai, et al. 2014. The Impact of Online Shopping Experience on Risk Perceptions and Online Purchase Intentions: Does Product Category Matter?. Journal of Electronic Commerce Research. 15 (1): 13-24.

Delafrooz et al. 2009. Factor Affecting Students's Attitude Toward Online Shopping. African Journal of Business Management. 3 (5): 200-209.

Ghozali, I., dan Fuad. 2005. Structural Equation Modeling: Teori, Konsep, dan Aplikasi dengan Program Lisrel 8.54. Badan Penerbit Universitas Diponegoro. Semarang.

Hajli, N. 2013. A Study of the Impact of Social Media on Consumers. International Journal of Market Research. 56 (3): 387-404.

Hariyanto. 2012. Pendekatan, Jenis dan Metode Penelitian Pendidikan. https://belajarpsikologi.com/pendekatanjenis-dan-metode-penelitian-pendidikan/. Diakses Tanggal 08 September 2018.

Jaafar, S.N., Lalp, P.E., dan Naba, M.M. 2013. Consumers' Perceptions, Attitude, and Purchase Intention Towards Private Label Food Products in Malaysia. Asian Journal of Business and Management Sciences. 2 (8): 73-90.

Jahangir, N. dan Begum, N. 2008. The Role of Perceived Usefulness, Perceived Ease of Use, Security and Privacy, and Customer Attitude to Engender Customer Adaptation in the Context of Electronic Banking. African Journal of Business Management. 2 (1): $32-40$.

Jamaludin, A. 2013. Investigating the Relationship between Trust and Intention to Purchase Online. Business and Management Horizons. 1 (1): 1-9.

Kim, J. 2004. Understanding Consumers' Online Shopping and Purchasing Behaviors. Disertasi. Oklahoma State University.

Lake, C. 2009. What is Social Media? Here are 34 Definitions. www.econsultanc y.com/blog/3527-what-is-social-media-he re-are-34-definitions. Tanggal Diakses 13 
April 2018.

\section{Laksana, N.C. 2018. Ini Jumlah Total Pengguna} Media Sosial di Indonesia. https://techno.okezone.com/read/2018/03/13 /207/1872093/ini-jumlah-total-penggunamedia-sosial-di-indonesia. Diakses Tanggal 08 September 2018.

Leeraphong, A dan Mardjo, A. 2013. Trust and Risk in Purchase Intention through Online Social Network: A Focus Group Study of Facebook in Thailand. Journal of Economics, Business and Management. 1 (4): 314-318.

Li, N., dan Zhang, P. 2002. Consumer Online Shopping Attitude and Behavior: An Assessment of Research. Prosiding Eighth Americas Conference on Information Systems.

Mahendra, I. 2015. Analisa Penerimaan Pengguna Sistem Informasi Koperasi Pada Koperasi Karyawan Budi Setia Jakarta dengan Technology Acceptance Model. Jurnal Pilar Nusa Mandiri. 11 (1): 70-80.

Mayfield, A. 2008. What is Social Media?. Creative Commons. California.

Mirabi, V., Akbariyeh, H., dan Tahmasebifard, H. 2015. A Study of Factors Affecting on Customers Purchase Intention. Journal of Multidisciplinary Engineering Science and Technology. 2 (1): 267-273.

Pratomo, A.G. 2016. Peran Penting Media Sosial dalam Pengembangan Bisnis. https://techno.okezone.com/read/2016/11/16 /207/1543330/ peran-penting-media-sosialdalam-pengembangan-bisnis. Diakses Tanggal 08 September 2018.

Prihadi, S.D. 2017. Peta Persaingan Situs eCommerce di Indonesia. https://www .cnnindonesia.com/teknologi/201703151041 48-185-200219/peta-persaingan-situs-ecommerce-di-indonesia. Diakses Tanggal 08 September 2018.

Primus, J. 2018. Media Sosial Masih Jadi Pengubah Perilaku Belanja. https://ekonomi.kompas.com/read/2018/07/2 4/212200326/media-sosial-masih-jadi- pengubah-perilaku-belanja. Diakses Tanggal 09 September 2018.

Putro, H. dan Haryanto, B. 2015. Factors Affecting Purchase Intention of Online Shopping in Zalora Indonesia. British Journal of Economics, Management, and Trade. 9 (1): 1-12.

Rizwan, Muhammad. 2014. Determinats of Customer Intentions for Online Shopping: A Study from Pakistan. Journal of Sociological Research. 5, (1): 248-272.

Sugiyono. 2013. Metode Penelitian Kuantitatif Kualitatif dan $R \& D$. Alfabeta. Bandung.

Trevinal, A. M., Coupey, dan Stenger. 2015. The Online Shopping Experience (OSE): Towards the Development of a Four-order Hierarchical Model. Prosiding Conference Paper of $18^{\text {th }}$ Conference of the European Association for Education and Research in Commercial Distribution.

Vinerean, et al. 2013. The Effects of Social Media Marketing on Online Consumer Behavior. International Journal of Business and Management. 8 (14): 66-79.

Wahyono, B. 2013. Definisi dan Pengertian Structural Equation Modeling (SEM). http://www.pendidikanekonomi.co $\mathrm{m} / 2013 / 05 /$ definisi-dan-pengertian-structu ral.html, Diakses Tanggal 08 September 2019.

Wang, P., Gudergan, S., dan Lings, I. 2008. The Role of Product Involvement in e-Service Evaluations. International Journal of Electronic. 2 (1): 59-79.

Yamin, S. D. (2009). Structural Equation Modeling: Belajar Lebih Mudah Teknik Analisis Data Kuesioner dengan Lisrel-PLS. Salemba Infotek. Jakarta. 